\title{
Universiteit
}

Leiden

The Netherlands

\section{Judicial review of revocation decisions in the context of European banking supervision \\ Budinská, B.}

\section{Citation}

Budinská, B. (2019). Judicial review of revocation decisions in the context of European banking supervision. Review Of European Administrative Law, 12(1), 175-193.

doi:10.7590/187479819X15656877527241

Version: Publisher's Version

License: $\quad$ Licensed under Article 25fa Copyright Act/Law (Amendment Taverne)

Downloaded from: $\quad$ https://hdl.handle.net/1887/3217447

Note: To cite this publication please use the final published version (if applicable). 


\title{
Judicial review of revocation decisions in the context of European banking supervision
}

\author{
Barbora Budinska* \\ LLM; PhD candidate at the Europa Institute of Leiden Law School
}

\begin{abstract}
The Single Supervisory Mechanism (SSM), a system centralising banking supervision in Europe, is comprised of the European Central Bank (ECB) and the national competent authorities (NCAs). The paper focuses on a new phenomenon occurring within the SSM, the so-called Top-Down revocations which might require the Court of Justice (Court), while reviewing a decision of the $E C B$, to also incidentally review a decision of an NCA. The paper first shows that such an incidental review creates a tension between, on the one hand, the principle of legality, thus the Court's obligation to review EU acts and, on the other hand, the principle of EU law autonomy which prohibits situations where EU law depends in its interpretation, validity or application on national law. Second, the paper analyses Court's case law on 'derivative illegality' and argues that the Court's approach adopted there can be carefully applied to Top-Down revocations. Finally, it argues that the Court can review such revocation decisions in three situations: (1) when the review of the revocation decision suffices to determine the unlawfulness of the national measure; and when the lawfulness of the national act can be assessed in the light of (2) EU procedural law; and (3) EU substantive law.
\end{abstract}

\section{Introduction}

In 2014, the creation of the Single Supervisory Mechanism (Supervisory Mechanism or Mechanism) centralised banking supervisory powers in the Eurozone and put them in the hands of the European Central Bank (Bank). In the day-to-day prudential supervision of credit institutions, the Bank cooperates with the National Competent Authorities (national authorities).

The unique institutional set-up, and the particular competence division within the Mechanism, give rise to a host of unprecedented challenges. This paper aims at addressing one of these challenges, namely the question of judicial

* DOI 10.7590/187479819X15656877527241 1874-7981 2019 Review of European Administrative Law

I would like to thank Professor Stefaan Van den Bogaert, Dr. Vestert Borger, Dr. Felipe Brito Bastos and the participants of the workshop 'Accountability and Control of European Multilevel Administration: Current Challenges in EU Administrative Law' organised by the Amsterdam Centre for European Law and Governance at the University of Amsterdam as well as the anonymous reviewers for their valuable feedback. All flaws and mistakes in the paper remain my own. E-mail: b.budinska@law.leidenuniv.nl. 
review of Top-Down revocation decisions. Such decisions occur when the Bank revokes a decision previously adopted by a national authority. In a review of such a revocation, the Court of Justice of the European Union (Court) will inevitably be confronted with the question of whether, and if so, to what extent, it can review the original decision made by the national authority. Such an incidental review might be necessary in order to assess the validity of the Bank's revocation decision. Yet, it might require the Court to review the decision of the national authority in light of national law, which is at odds with the principle of autonomy stipulating that European Union measures can only be reviewed in light of European Union law, not national law.

The paper argues that while the phenomenon of Top-Down revocations is a new one, the underlying tension that arises with it between the principles of legality of European Union acts and the autonomy of the Union legal order, has previously been addressed by the Court in the cases of so-called derivative illegality. Therefore, the paper tests the applicability of the Court's approach to derivative illegality on cases of revocation decisions. It is divided as follows: First, it explains the competence division within the Supervisory Mechanism. Second, it discusses the question of the revocability of administrative decision in Union law and within the Supervisory Mechanism. Third, the paper maps the case law on derivative illegality in composite procedures and tests its applicability to cases of revocation decisions. The paper concludes that the Court can review national decisions revoked by the Bank in three distinct situations: (1) when the review of the revocation decision suffices to determine the unlawfulness of the national measure; (2) when the lawfulness of the national act can be assessed in light of European Union procedural law, and (3) Union substantive law as defined by Article 4(3) Basic Regulation.

\section{The competence division within the framework of the Mechanism}

The Supervisory Mechanism ${ }^{1}$ is the first pillar of the European

Banking Union. ${ }^{2}$ Its primary task is the prudential supervision of credit institu-

The Mechanism was established by Council Regulation (EU) 1024/2013 conferring specific tasks on the European Central Bank concerning policies relating to the prudential supervision of credit institutions [2013] OJ L 287/63 (henceforth: Basic Regulation). The legal basis of the Basic Regulation is Article 127(6) TFEU.

2 For a broader overview, see Danny Busch \& Guido Ferrarini (ed.), European Banking Union (OUP 2015). 
tions $^{3}$ (here also referred to as supervised institutions or supervised entities) within the Eurozone. ${ }^{4}$

The Mechanism, as such, does not have a legal personality of its own; ${ }^{5}$ it constitutes a multilevel administrative system of financial supervision composed of the Bank and the national authorities ${ }^{6}$ of the participating Member States. As Teixeira expresses it, the 'SSM consists of a unique and unprecedented juxtaposition of European and national competences, which defies any clear definition or categorisation'. 8 The framework of the Mechanism identifies several layers or types of competences allocated to the Bank, to the national authorities or to both. The Bank is responsible for the overall functioning of the Mechanism; ${ }^{9}$ it has an exclusive competence to supervise the group of banks classified as significant credit institutions, ${ }^{10}$ and an oversight competence over the national authorities with the power to issue instructions. ${ }^{11}$ The national authorities supervise the less significant credit institutions. ${ }^{12}$ Moreover, the legal framework foresees shared and parallel competences of the Bank and the national authorities, as well as composite procedures in which the Bank and the national authorities work together to execute supervisory tasks. ${ }^{13}$ Finally, tasks not conferred on the Bank by the Basic Regulation remain in the competence of the national authorities. ${ }^{14}$ The precise rules and the practical aspects of the cooperation between the Bank and the national authorities are laid down in a

3 More precisely credit institutions, financial holding companies and mixed financial holding companies, as well as branches of credit institutions established in non-participating Member States, cf Article 6(4) and Article 2(3)(4)(5) Basic Regulation.

4 Article 1(1) Basic Regulation; for the regulation of the opt-in for non-Eurozone Member States, see Article 7 Basic Regulation.

5 Cf Christos V. Gortsos, 'Competence Sharing between the ECB and the national competent supervisory authorities within the single supervisory mechanism (SSM)' [2015] 16(3) Eur Bus Org Law Rev 401, 405; see also Article 2(9) Basic Regulation.

6 Cf Article 2(2) Basic Regulation.

7 Cf Articles 2(9), 6(1) Basic Regulation.

8 Pedro Gustavo Teixeira, 'Europeanising prudential banking supervision: Legal foundations and implications for European integration' in John Erik Fossum \& Augustín José Menéndez (eds.), The European Union in Crises or the European Union as Crises?, ARENA Report No 2/14, 527, 554 .

9 Cf Article 6(1) Basic Regulation.

10 Article 2(16)(17)(18) Framework Regulation.

11 Cf Article 6(5)(a)(c) Basic Regulation.

12 Cf Article 2(7)(8) Framework Regulation.

13 Teixeira (n. 8) 554; for an overview of the competence allocation, see also by the same author, 'The Single Supervisory Mechanism: Legal and Institutional Foundations', [2013] 75 Quaderni di Ricerca Giuridica ella Consulenza Legale: Dal Testo unico bancario all'Unione bancaria: tecniche normative e allocazione di poteri 75, 83-86; Edoardo Chiti \& Fabio Recine, 'The Single Supervisory Mechanism in Action: Institutional adjustment and the reinforcement of the ECB position', [2018] 24(1) European Public Law 101.

14 E.g. rules on consumer protection or money laundering, cf Recital 28 Basic Regulation. 
Framework Regulation ${ }^{15}$ adopted by the Bank on the basis of Article 6 Basic Regulation. ${ }^{16}$

\section{Significant and less significant credit institutions}

For the purposes of direct supervision, the Basic Regulation divides the supervised institutions into significant credit institutions and less significant credit institutions. ${ }^{17}$ The Bank has direct supervisory competences over the significant institutions, while the national authorities carry out the direct supervisory tasks over the less significant institutions. ${ }^{18}$ The distinction between the significant and the less significant credit institutions is one of the main decentralising features of the supervisory framework. ${ }^{19}$

The legal framework governing the classification of credit institutions is laid down in Articles 6(4)-(8) Basic Regulation in conjunction with Articles 3972 Framework Regulation. ${ }^{20}$ According to these rules, the general determining factors are (1) the size, (2) the importance for the economy of the Union or any participating Member State, and (3) the significance of cross-border activities. ${ }^{21}$ The decision to classify an institution as significant is taken by the Bank. ${ }^{22}$

15 Regulation (EU) 468/2014 of the European Central Bank establishing the framework for cooperation within the Single Supervisory Mechanism between the European Central Bank and national competent authorities and with national designated authorities [2014] OJ L 141/1 (henceforth: Framework Regulation).

16 Cf Gortsos (n. 5) 402.

17 Article 6(4) Basic Regulation.

18 This dichotomy does not apply to the competence of granting/withdrawing an authorisation and the competence of authorisation of an acquisition of qualifying holdings - a final decision as regards these two competences is vested with the Bank irrespective of the credit institution, cf Article 4(1)(2) Basic Regulation.

19 Teixeira (n. 8) 560.

20 Particularly, the criteria for the assessment of significance of a credit institution are stipulated in Articles 50-66, 70-72 Basic Framework Regulation, see also Klaus Lackhoff, 'Which credit institutions will be supervised by the single supervisory mechanism?' (2013) 28(11) J.I.B.L.R. 454, 457 et seq.; Klaus Lackhoff, 'The Framework Regulation (FR) for the Single Supervisory Mechanism (SSM) - an overview' (2014) 29(8) J.I.B.L.R. 498, 505 et seq.

21 The Basic Regulation prescribes that a credit institution shall not be considered less significant if either the total value of its assets exceeds 30 billion EUR, or the ratio of its total assets over the GDP of the participating Member State of establishment exceeds $20 \%$, or if such a credit institution is considered significant for the domestic economy. Additionally, the Bank may also, on its own initiative, consider an institution to be of significant relevance where it has established banking subsidiaries in more than one participating Member State and its crossborder assets or liabilities represent a significant part of its total assets or liabilities. Finally, those credit institutions which have requested or are receiving financial assistance from either the EFSF or the ESM, as well as the three most significant institutions in each of the participating Member States shall be considered significant cf Article 6(4).

22 Article 39(1) in conjunction with Article 44(2) Framework Regulation. As long as a credit institution does not receive a decision from the Bank rendering the former significant, this credit institution is considered less significant, cf Article 44(3) Framework Regulation; for an excellent detailed overview see Patrick Hilbert, 'Vertikale Aufhebungsentscheidungen, Zu einem neuen Phänomen der Verbundverwaltung im Europäischen Bankenaufsichtsrecht' (2017) 50 Die Verwaltung 189,194 . 
Given the above mentioned factors, it is clear that the classification of any particular credit institution can change over time. ${ }^{23}$ Consequently, with the change of classification comes a change of the supervisor; i.e. a credit institution which was supervised by a national authority will be supervised by the Bank and vice versa. Such a change will be effected by a decision of the Bank. ${ }^{24}$

In general, the Bank shall review on at least an annual basis, whether those credit institutions which are classified as significant still continue to fulfil the criteria of Article 6(4) Basic Regulation. ${ }^{25}$ A status review can be, however, also carried out by the Bank at any time in case it receives relevant information that a significant credit institution does not fulfil the criteria in Article 6(4) of the Basic Regulation, or, alternatively, that a less significant credit institution does fulfil one or more of the said criteria. ${ }^{26}$

\section{The phenomenon of revocation}

Due to a change in the classification of a supervised entity, the day-to-day supervision passes from the 'old' supervisor to the 'new' one. ${ }^{27}$ This general rule is subject to a caveat in cases of the so-called 'pending procedures' stipulated in Article 48 Framework Regulation. It clarifies that if the authority whose competence ends does not conclude formally initiated procedures before the competence change occurs, it remains competent to complete these procedures and consequently, also retains all relevant powers. ${ }^{28}$

The Framework Regulation, however, does not specifically address situations in which the authority whose supervision has ended, finalized a supervisory procedure (e.g. by adopting a final decision addressed to the supervised entity)

23 The current list of significant credit institutions can be found here: https://www.bankingsupervision.europa.eu/ecb/pub/pdf/ssm.list_of_supervised_entities_201901 cc1oda7690.en.pdf, accessed 03.06.2019.

24 Either the Bank takes a decision addressed to a credit institution pursuant to Articles 39(1), 44(2), 45(1) Framework Regulation to declare a less significant institution significant; or, alternatively, according to Article 39(2) Framework Regulation, the Bank can also declare a previously significant credit institution less significant. This decision to classify a credit institution less significant will be followed by another Bank's decision clarifying why and when it will stop being the direct supervisor of the said credit institution, see Article 46(1) Framework Regulation; cf also Case C-450/17 P Landesbank Baden-Württemberg - Förderbank v ECB EU:C:2019:372. Here, a credit institution dissatisfied with its classification as significant institution brought an action for annulment pursuant to Article 263 TFEU.

25 All national authorities have the same obligation as regards the less significant credit institutions, Article 43(1)(2) Framework Regulation.

26 Article 43(3)(4) Framework Regulation. Yet, as a guideline, Recital 40 Basic Regulation suggests that once a credit institution has been classified as either significant or less significant, such an assessment should, in general, not be modified more often than once every 12 months, unless exceptional circumstances would justify otherwise.

27 Article 45(1) Framework Regulation.

28 Article 48(3) Framework Regulation. 
and the new supervisory authority subsequently interferes with this final decision, e.g. by amending or revoking it. For example, first, a national authority imposes a pecuniary penalty on a credit institution for non-compliance with a supervisory decision. ${ }^{29}$ After a change of the supervisor, the Bank repeals and replaces this penalty with a higher one. Alternatively, a national authority appoints a special manager to take over the management of a less significant institution,,$^{30}$ and after the change of the supervisor, the Bank revokes the appointment. ${ }^{31}$ Or, a national authority imposes a certain number of own funds an entity needs to hold based on an assessment of its risk aversion. Subsequently, the Bank makes a new assessment of the supervised entity for the same period and decides to impose additional own funds requirements. ${ }^{32}$ All these measures of the Bank might constitute either a partial or a full revocation of the initial decision made by a national authority. The question arises whether, and if so, to what extent such revocation is possible under Union law.

\section{Revocability under European Union law}

\section{General principles}

The revocation of administrative decisions does not constitute a novelty. ${ }^{33}$ The question whether an administrative decision could be withdrawn by the body that took it was discussed by the Court as early as in 1957 in Algera. ${ }^{34}$ Ms Algera contested a decision taken by the Common Assembly to revoke her employment appointment. The Court first addressed the general possibility of revocation stating that it is a problem of administrative law, which is familiar in [...] all the countries of the Community, but for the solution of which the Treaty does not contain any rules. Unless the Court is to deny justice it is therefore obliged to solve the problem by reference to the rules acknowledged

29 Cf Article 18 Basic Regulation in conjunction with Article 123ff. Framework Regulation.

30 Cf Article 97(2)(a), Article 98(2)(a) Framework Regulation.

31 Cf Article $16(2)(\mathrm{m})$ Basic Regulation in conjunction with Article 91 Framework Regulation.

32 Cf Article 104(1)(a) and (2) Directive 2013/36/EU of the European Parliament and of the Council on access to the activity of credit institutions and the prudential supervision of credit institutions and investment firms, amending Directive 2002/87/EC and repealing Directives $2006 / 48 / \mathrm{EC}$ and 2006/49/EC [2013] OJ L 176/338.

33 It is also a known concept in many national jurisdictions, e.g. for English and French law see e.g. Søren J. Schønberg, 'Substantive protection of Legitimate Expectations (I): Revocation of Decisions' in Søren J. Schønberg, Legitimate Expectations in Administrative Law (OUP 2000) 64-106; or for German law see e.g. Günther Kiefer, 'Können rechtswidrige Verwaltungsakte widerrufen werden?’(2013) 19 NVwZ 1257; Andreas Voßkuhle \& Ann-Katrin Kaufhold, 'Grundwissen - Öffentliches Recht: Rücknahme und Widerruf von Verwaltungsakten' (2014) JuS 695 .

34 Joined Cases C-7/56 and C-3/57 to C-7/57 Algera v Common Assembly EU:C:1957:7. 
by the legislation, the learned writing and the case-law of the member countries. ${ }^{35}$ As to the revocability of the employment appointment in particular, the Court ruled that 'an administrative measure conferring individual rights on the person concerned cannot in principle be withdrawn, if it is a lawful measure; in that case, since the individual right is vested, the need to safeguard confidence in the stability of the situation thus created prevails over the interests of an administration desirous of reversing its decision. ${ }^{36}$

As the Algera judgment as well as the subsequent case law show, the underlying tension in cases of (ir)revocability result in the need to protect two elements: the principle of legality and that of legitimate expectations. In other words, the Court in deciding whether to revoke an administrative decision needs to balance the public interest in the legality of administrative action, with the private interest in individual justice. ${ }^{37}$ To decide whether a particular administrative decision can be revoked, the Court looks at three elements: (1) whether the revoked administrative decision was lawful, ${ }^{38}(2)$ whether it conferred a right on an individual, ${ }^{39}$ as well as, (3) whether the measure was revoked with a retroactive or a proactive effect. ${ }^{4}$

Lawful and favourable decisions are in principle irrevocable. ${ }^{41}$ A revocation is, however, possible as a matter of exception in cases where both parties agree on it, ${ }^{42}$ when the initial decision is obtained by fraud and/or deception ${ }^{43}$ or was subject to conditions, ${ }^{44}$ or where a change of policy might have an impact on the decision initially made and thus justify its revocation. ${ }^{45}$

35 Ibid 55 .

36 Ibid.

37 Cf Joined Cases 42 and 49/59 SNUPAT EU:C:1961:5; Case 14/61 Koninklijke Nederlandsche Hoogovens en Staalfabrieken N.V. v High Authority EU:C:1962:28.

38 Cf Herwig C.H. Hofmann, 'General Principles of EU law and EU administrative law' in: Catherine Barnard \& Steve Peers (eds.), European Union Law (OUP 2017) 210 et seq.

39 Here, the terminology of the Court is not uniform. In its initial case law on revocability, the Court spoke of administrative measures 'conferring individual rights'. However, later on, it broadened the concept to legal acts which confer rights or similar benefits (cf Case 159/82 Verli-Wallace $v$ Commission EU:C:1983:242), or are favourable in nature (cf Case C-90/95 P Henri de Compte v European Parliament EU:C:1997:198).

40 Cf SNUPAT (n. 37); Henri de Compte (n. 39).

$41 \quad$ Algera (n. 34) 55; Verli-Wallace v Commission (n. 39); Henri de Compte (n. 39); Case T-251/oo Lagardère und Canal+v Commission EU:T:2002:278; Case 14/81 Alpha Steel v Commission EU:C:1982:76; Case T-416/04 Kontouli v Council EU:T:2006:281; Case F-51/o7 RENV - Bui Van $v$ Commission EU:F:2008:112.

42 Cf Schønberg (n. 33) 79.

43 Although here, it might be questionable whether such a decision is still to be considered legal; cf e.g. Case C-96/89 Commission v Netherlands EU:C:1991:213.

44 Cf e.g. Case 121/83 Zuckerfabrik Franken GmbH v Hauptzollamt Würzburg EU:C:1984:175; Case T-81/95 Interhotel - Sociedade Internacional de Hotéis SARL v Commission EU:T:1997:117.

45 This category is more controversial, see Schønberg (n. 33) 84-88; Paul Craig, 'Legal Certainty and Legitimate Expectations', in Paul Craig, EU Administrative Law (OUP 2012) 560-561. 
When it comes to unlawful decisions, the Court has established first, that the illegality of an administrative measure does not make that measure automatically null and void ex tunc. ${ }^{4}{ }^{6}$ Second, the illegality of the measure does not render its revocability self-evident or unconditional. ${ }^{47}$ On the contrary, the Court has made it clear that even unlawful decisions are subject to a balancing exercise. On a case-by-case basis, the Court decides whether the principle of legality or the principle of legal certainty prevails; it takes into account the nature of the illegality, potential legitimate expectations of the person concerned (in particular in cases of retroactive revocation), the effect on third parties, and how much time passed between the adoption of the initial and the revocation decisions. ${ }^{48}$

\section{Revocation within the Supervisory Mechanism}

The Court's case law on revocation deals predominantly with situations where the initial decision is revoked by the administrative body which adopted it. The situation within the Mechanism after the change of supervisors is, however, slightly different. There, an additional difficulty arises; the question whether an administrative authority which did not take the initial decision, has the competence to revoke it.

As was pointed out, the Framework Regulation only stipulates the competence allocation in the so-called 'pending procedures' in Article 48 , i.e. in a situation where a final decision was not yet taken before the change of supervisors occurred. In contrast, the Framework Regulation is silent on the question of competence to revoke a decision previously taken by an authority whose supervision has ended. The consequence could, theoretically, be twofold: First, it could be argued that in case of revocation decisions, it is always the authority which takes the decision that is also solely competent for its revocation. This conclusion flows from the actus contrarius doctrine which stipulates that '[...] in principle, a body which has power to adopt a particular legal measure also has power to abrogate or amend it by adopting an actus contrarius, unless such power is expressly conferred upon another body [...]'. ${ }^{49}$

Second, and more convincingly, it can be argued that the competence to revoke a decision made by the former supervisor lies with the new supervisor. It is true that neither the Basic Regulation nor the Framework Regulation expressly stipulates the competence division for revocation decisions. However, it can be inferred from the existence of Article 48 Framework Regulation that the pending procedures constitute the only exception from the general rule that at

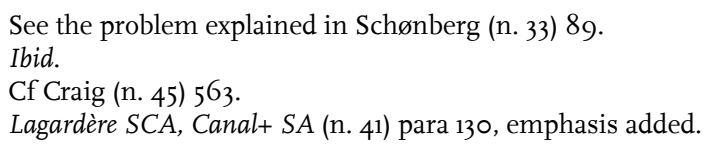


the moment the change of supervisors occurs, the old supervisor loses all its competences to address the credit institutions, while the new supervisor acquires them. It seems consequential also that the competence to revoke any previously made decisions is now vested with the new supervisor.

It is therefore argued that after a change in supervision, the new supervisor has the competence to revoke decisions initially made by the former supervisor. This means that, in general, a newly competent national authority can revoke decisions made by the Bank (Bottom-Up revocation) just as the newly competent Bank can revoke decisions made by a national authority (Top-Down revocation). ${ }^{50}$

Further, it needs to be pointed out that the above mentioned general principles and conditions of revocability of administrative decisions also apply to the Bank and the national authorities when acting within the supervisory framework. The Supervisory Mechanism does not establish a 'federal system' of banking supervision. The Basic Regulation has rather created a 'single system of competences where the ECB has overall responsibility and power over all its parts. ${ }^{.51}$ The Bank is therefore in a position of a 'functional prominence' vis-àvis the national authorities. ${ }^{52}$ This means that whatever competences the national authorities have acquired within the supervisory framework, they will carry them out in a manner defined by the Bank and under its oversight. ${ }^{53}$ However, it should not be concluded from this that the Bank has the power to arbitrarily revoke a decision adopted by a national authority (Top-Down revocation). As long as the Bank does not instruct a national authority to take a specific supervisory decision or does not assume full supervision over a less significant bank, the day-to-day prudential supervision over less significant institutions lies in the hands of the national authorities. Once a national authority adopts a final decision producing legal effects vis-à-vis its addressee(s) or third parties, such a decision might only be revoked in accordance with the conditions developed by the Court in Algera and subsequent case law.

50 For the same conclusion, see Hilbert (n. 22) 202-204.

51 Teixeira (2013) (n. 13) 85. Article 127(6) TFEU can confer supervisory competences only on the Bank, but not the national authorities. See also Gianni Lo Schiavo, 'From national banking supervision to a centralized model of prudential supervision in Europe? The stability function of the Single Supervisory Mechanism' (2014) 21(1) MJ 110, 126-132.

52 Chiti \& Recine (n. 13) 108.

53 Teixeira (n. 8) 560. 


\section{The Court's approach to derivative illegality and its applicability to revocation}

\section{Tension between the principles of legality and autonomy}

In the case of revocation within the Supervisory Mechanism, not only do different authorities take the initial and the revocation decision. They also come from different jurisdictions - the Bank is an institution of the European Union legal order, and the national authorities are governed by national law.

The general rule on jurisdiction is that the national courts have the competence to review decisions made by national authorities, ${ }^{54}$ and the Court is competent to review the measures taken by the Bank. ${ }^{55}$ It is argued here that the same holds also for the particular case of revocation decisions: if a national authority revokes a decision of the Bank, a national court has jurisdiction, while in a case where the Bank withdraws a decision of a national authority, the Court will have jurisdiction. It is not the revoked decision but rather the revocation decision which is subject to judicial review and is therefore decisive for the determination of jurisdiction.

The competent court will, however, face a difficulty: in order to determine the validity of the revocation, it might have to review the lawfulness of the initial decision. In other words, a national court reviewing a revocation decision adopted by a national authority might need to review the legality of the Bank's initial decision. By the same token, the Court reviewing a revocation decision of the Bank might need to review a measure of a national authority.

The review poses less of a challenge for national courts since they have the competence to apply Union law. ${ }^{56}$ Moreover, they can always reach out to the Court and request an interpretation or a review of the validity of the initial measure. ${ }^{57}$ The Court, however, does not have a similar option of a 'reverse' preliminary question..$^{8}$ The Top-Down revocation gives therefore rise to a ten-

54 Although this rule appears to be subject to exceptions as we can see in the recent ruling of the Court in Joined Cases C-202/18 and C-238/18 Ilmārs Rimšēvičs and European Central Bankv Republic of Latvia EU:C:2019:139.

55 Admittedly, these originally strict jurisdictional limits have become slightly blurred after the Court assumed jurisdiction to review preparatory measures of national authorities in the procedure of authorisation of an acquisition of a qualifying holding, see Case C-219/17 Berlusconi and Fininvest EU:C:2018:1023.

56 Even though they cannot invalidate it, see Case 314/85 Foto-Frost $v$ Hauptzollamt Lübeck-Ost EU:C:1987:452 para 17 .

57 Article 267 TFEU.

58 Mariolina Eliantonio, 'Judicial Review in an Integrated Administration: the Case of "Composite Procedure”' (2014) 7(2) REALaw 65-102; Herwig C.H. Hofmann, 'Composite Procedures in the EU Administrative Law’, in Herwig C.H. Hofmann \& Alexander Türk (eds.), Legal Challenges in EU Administrative Law: The Move to an Integrated Administration (Elgar Publishing 2009) 158; on the Court's prohibition to interpret national law see e.g. Case C-62/14 Gauweiler and Others EU:C:2015:400 para 26; Case C-621/18 Wightman and Others EU:C:2018:999 para 30. 
sion: On the one hand, under Article 19(1) TEU, the Court has an obligation to guarantee the legality of Union administrative action. The Court, therefore, has to determine the validity of any measure challenged before it. ${ }^{59}$ In order to comply with this obligation in revocation cases the Court, in line with its established case law since Algera, needs to review the validity of the national measure.

On the other hand, such a review however seems to be at odds with the principle of autonomy. ${ }^{60}$ Developed by the case law of the Court, this principle stipulates that Union law is self-referential, i.e. 'EU law decides how EU law works, when it applies and what it says ${ }^{6}{ }^{61}$ In other words, one of the core premises of the principle is the prerequisite that the European Union legal order is grounded in an independent source of law - the Treaties. ${ }^{62}$ This means that the validity of Union measures can only be judged in the light of Union law of higher rank, not national law. ${ }^{6}$ In case of Top-Down revocation the Court is therefore faced with a challenge to balance the principle of legality with that of autonomy.

\section{The concept of derivative illegality}

It is not the first time that the Court would be required to reconcile the tension between these two principles. A necessity for a balancing exercise also arises in cases of the so-called derivative illegality, a phenomenon predominantly occurring in composite procedures of the Union multilevel administration. ${ }^{64}$ In broad terms, multilevel administration describes the new

59 Provided that an action for annulment complies with the admissibility criteria. For the notion of a reviewable act see, e.g. Case 6o/81 IBM v Commission EU:C:1981:264; Case T-492/93 and T-492/93 R Nutral SpA v Commission EU:T:1993:85.

60 Cf Case 6/64 Costa / E.N.E.L. EU:C:1964:66; Opinion 2/13 Accession of the Union to the ECHR EU:C:2014:2454; Opinion 1/91 EEA Agreement EU:C:1991:490; C-459/03 Commission v Ireland EU:C:2006:345; C-402/05 P and C-415/05 P Kadi and Al Barakaat International Foundation v Council and Commission EU:C:2008:461; Case C-284/16 Slowakische Republik (Slovak Republic) $v$ Achmea BV EU:C:2018:158. On the various elements of the principle of EU law autonomy, see e.g. Loic Azoulai, 'The Europeanization of legal concepts', in Ula B. Neergard \& Ruth Nielsen (eds.), European Legal Method: In a Multi-layered EU Legal Order (DJØF Publishing 2012) 165-182; René Barents, The Autonomy of Community Law (Kluwer Law International 2004); Jan Willem van Rossem, 'The Autonomy of EU Law: More is Less?' in Ramses A. Wessel \& Steven Blockmans (eds.), Between Autonomy and Dependence. The EU Legal Order Under The Influence of International Organisations (T.M.C. Asser Press/Springer 2013) 13-46.

61 Armin Cuyvers, 'Solving the autonomy conundrum: a hard border in Northern-Ireland?' (2018) Leiden Law Blog, https://leidenlawblog.nl/articles/solving-the-autonomy-conundrum-a-hardborder-in-northern-ireland, accessed 3 June 2019.

62 Cf Case 26/62 Van Gend en Loos EU:C:1963:1.

63 Case 11/70 Internationale Handelsgesellschaft EU:C:1970:114 para 3.

64 An in-depth analysis of the term 'derivative illegality' as a problem arising particularly in composite procedures of the Union multilevel administration structures is to be found in Felipe Brito Bastos, 'Derivative illegality in European administrative composite procedure' (2018) 55 CML Rev 101. It should be noted that the notion of derivative illegality is not restricted to decisionmaking processes in composite procedures but can refer to any form of 'contamination' of one decision by illegality of another. 
and fast developing reality in which national and Union administrative bodies cooperate closely in network structures. ${ }^{65}$ Banking supervision is only one in many Union policy fields in which the administrative structures on the Union and the national level are closely intertwined. Decision-making processes in the agricultural sector, structural funds, customs law, GMO regulation, the rules on access to documents possessed by Union institutions, and elections for the European Parliament are also governed by legal frameworks creating multilevel administration systems. ${ }^{66}$

The decisions made by multilevel administration are often adopted in the so-called composite procedures. These are multiple-step procedures in which the final administrative act or decision is a result of different administrative authorities from various levels exercising their respective powers conferred on them by the relevant legal framework. Although the final act as such is issued by either a Union or a national administrative authority, it is a product of more or less binding 'input' from administrative authorities from different jurisdictions. $^{67}$

While the precise cooperation and competence division between the Union and the national level is determined by the particular legal framework, three types of composite procedures have become prominent across different policy fields: (1) the national administration conducts the whole procedures and drafts a preparatory measure for the Union administrative authority which merely rubber-stamps it without having any discretion; (2) the national administration drafts a preparatory measure and submits it to the Union authority which has discretion to diverge from the draft, and (3) the Union administration decides the matter essentially by itself with marginal assistance by the national authorities.

As long as the 'final decision-making power' lies with the Union authority, the Court will be the one competent to review such a decision. ${ }^{68}$ A problem arises when an applicant in an action for annulment, claims that the Union measure was invalid due to the fact that the preceding national measure was unlawful. The Court faces a challenge: it has the obligation to review and determine the legality of the Union measure, yet it has to incidentally review the

65 This phenomenon is also described as composite, integrated or shared administration. For the description and analysis of the EU administrative order, see e.g. Paul Craig, EU Administrative Law, 2nd ed. (OUP 2012) 27 et seq.; Herwig C.H. Hofmann \& Alexander Türk, 'The development of integrated administration in the EU and its consequences' (2007) 13 ELJ 253; Eberhard Schmidt-Aßmann, 'Introduction: European composite administration and the role of European administrative law', in Eberhard Schmidt-Aßmann \& Bettina Schöndorf-Haubold (eds.), The European Composite Administration (Intersentia 2011) 1.

66 Cf Opinion of AG Campos Sánchez-Bordona in Case C-219/17 Berlusconi and Fininvest EU:C:2018:502 para 3, for an in-depth overview, see Wolfgang Kahl, 'Der europäische Verwaltungsverbund: Strukturen-Typen-Phänomene' (2011) 50(3) Der Staat 353.

67 See e.g. Eliantonio (n. 58) 65-102.

68 Cf Berlusconi and Fininvest (n. 55) paras 43-45. 
lawfulness of the preparatory measure adopted in the national stage of the composite procedures. In other words, the Court has to balance the principle of legality with that of autonomy.

\section{Case law on derivative illegality}

In order to reconcile these two principles in the review of composite procedures decisions, the Court has adopted a rather differentiated approach. The seminal case is Borelli. ${ }^{6}$ Oleificio Borelli, an Italian company, submitted an application for aid from the European Agricultural Guidance and Guarantee Fund to build an oil mill. According to the applicable law, ${ }^{70}$ the application was assessed by the Italian authority which issued an unfavourable opinion and forwarded it to the European Commission. The Commission informed Oleificio Borelli about the outcome of the procedure. The latter subsequently submitted an action for annulment to the Court requesting for it to declare the Commission decision not to grant the aid invalid. Borelli argued that the administrative measure adopted by the Italian authority was illegal due to an erroneous assessment made by the national authority, which resulted in a negative opinion submitted to the Commission. This negative opinion was classified as a preparatory measure under Italian law which excluded the possibility of review by Italian courts. ${ }^{71}$ The only final measure was the one adopted by the Commission, which meant that the Court was the only forum for the applicant to bring its claim. Borelli argued that if the invalidity of the national preparatory measure were to have no effect on the validity of the final Commission decision, Borelli would effectively be deprived of any judicial redress.

The Court stated that it has no jurisdiction to rule on the validity of national measures and that this lack of jurisdiction applies also to national measures which are part of EU composite procedures since 'it clearly follows from the division of powers in the field in question between the national authorities and the Community institutions that the measure adopted by the national authority is binding on the Community decision-taking authority and therefore determines the terms of the Community decision to be adopted. ${ }^{72}$

The Court further explained that, according to the applicable legislation, the Commission had no discretion to review the lawfulness of the opinion adopted by the national authority. It then concluded that any irregularity of the preparatory measure adopted on the national level cannot affect the legality of the Commission decision. Furthermore, the Court stated that it is for the national

\footnotetext{
69 Case C-97/91 Borelli v Commission EU:C:1992:491.

70 Council Regulation (EEC) 355/77 on common measures to improve the conditions under which agricultural products are processed and marketed [1977] No L 51 / 1.

71 For European Union law, see IBM v Commission (n. 59).

72 Borelli (n. 69) para 10.
} 
courts, in constellations such as the one at hand, to rule on the lawfulness of the national measure, treating the same virtually as a final decision having legal effects vis-à-vis third parties. Accordingly, the Court dismissed the application, refusing to review the legality of the Commission decision.

The importance of the Borelli judgment is twofold: first, it touches upon the two most pertinent problems of judicial review of measures adopted in composite procedures: the questions of the correct forum and of substantive review. In other words, it alludes to the question which court has jurisdiction over such a measure, as well as the question whether the competent Court is able to review the Union measure specifically on the ground of derivative illegality.

The second important insight of the Borelli judgment lies in the recognition that the Court is (implicitly) aware of the need for striking a balance between the principle of autonomy and its obligation to guarantee legality of Union (composite) administrative action. As the Commission had no discretion to change or deviate in any way from the 'binding opinion' of the national authority, any review of the final measure would be, essentially, tantamount to a review of the national preparatory measure. This would in turn mean that the legality of the Commission decision would be examined in the light of national law. The principle of autonomy therefore prevails in cases where the Union actor does not have any discretion. In an attempt to close the gap in judicial protection of the applicant, the Court requested the national courts to review the substance of the national preparatory measure.

Therefore, in cases where the national authority is competent to adopt a binding opinion within the framework of a Union decision-making procedure, and this opinion is binding on the EU authority which has no discretion to review the national authority's assessment of facts or law, the outcome of a review of such a final Union measure will be the same as in Borelli; the Court will dismiss the action to invalidate the Union measure, and it will consider the national court competent to review the binding opinion of the national administrative authority. The Court has confirmed this approach in its subsequent case law. ${ }^{73}$

The more discretion (also: 'real'74 or 'final decision-making power'75) is conferred on the Union authority in a composite procedure, the more willing the

\footnotetext{
Cf e.g. Case C-269/99 Carl Kühne and Others EU:C:2001:659.

Opinion of AG Campos Sánchez-Bordona Berlusconi and Fininvest (n. 66) para 60.

Berlusconi and Fininvest (n. 55) paras 43-45.
} 
Court is to admit derivative illegality as a ground for review of the final Union act. $^{76}$ Subsequent case law of the Court has shown this. ${ }^{77}$

The criterion of discretion also implies that it cannot be assumed that the derivative illegality is automatic, i.e. that just because a national measure is unlawful, the Union measure following the national one must automatically be unlawful too. ${ }^{78}$ In Pfizer, the national authority adopted a ban on the use of antibiotics in animal feedingstuff and informed the Council. Subsequently, the Council adopted a Regulation removing the antibiotics from the list of additives permitted in the internal market. The applicant argued before the Court that the Council Regulation was unlawful due to the fact that it was adopted on the basis of the national measure. The Court, however, dismissed the argument of contamination and stated that it is solely the Council regulation whose lawfulness is in question since the Council has the competence to make its own risk assessment, i.e. possessing the necessary discretion to diverge from the assessment and conclusions of the national authority.

To sum up, there are cases such as Borelli where the Court refused to review a Union measure due to the fact that the decision-making power lay solely with the national authority. There are cases such as Pfizer where the Court reviews the Union measure while disregarding the influence a national preparatory measure might have on the former due to the fact that the Union authority possesses all the decision-making power. In-between these two situations stand cases where the Union authority has the decision-making power to make a final decision, yet it partially relies on the input from a national authority. That means that if the national measure is erroneous, it might influence the validity of the final Union measure.

Even though the Court has until now ruled on a 'case-by-case and no-exhaustive basis on the judicial review of these composite procedures', ${ }^{79}$ three conditions have been established in the academic literature under which the Court is willing to accept derivative illegality as a ground for a review. First, the illegality stemming from the national measure must be imputable to the Union measure. Second, the illegality of the national measure must stem from a provision of Union law (or depict a standard of Union law). Third, a violation of a procedural measure can only be claimed in an action for annulment if this violation classifies as a violation of procedural requirements as understood under

\footnotetext{
76 See the newest assessment in Berlusconi and Fininvest (n. 55) para 45.

77 See e.g. Case C-478/93 The Netherlands v Commission EU:C:1995:324; Case C-6/99 Greenpeace France and Others EU:C:2000:148; Case C-64/05 P Sweden v Commission EU:C:2007:802.

78 See Case T-13/99 Pfizer Animal Health SA v Council of the European Union EU:T:2002:209.

79 Opinion of AG Campos Sánchez-Bordona Berlusconi and Fininvest (n. 66) para 59.
} 
Article 263(2) TFEU. ${ }^{80}$

The first condition serves to ensure that the Court's review is actually directed at a discretionary measure adopted by a Union institution. At the same time, other than in Pfizer, the unlawfulness of the Union measure must originate from a national measure, i.e. 'the EU authority must adopt a behaviour that prolongs those illegalities into the final EU measure'. ${ }^{81}$ This is, for example, the case where the Union administrative authority had the obligation to correct a mistake or an erroneous assessment of the national authority, and failed to do so. Such a duty will be recognized by the Court in composite procedures where both levels of administration have the power of appraisal regarding the same subject-matter. $^{82}$ The Court essentially stated that the national and the Union authority had the competence to make an assessment on the same subject matter which, in turn, implied that the Union authority, i.e. the authority taking the final discretionary decision on this matter, has the duty of correcting potential mistakes made by the national authority. In cases where the administrative authorities decide on separate issues, the Court denied the duty to correct. ${ }^{83}$

The second and third conditions aim to guarantee that the Court will assess a Union measure solely in the light of Union law, not national law. This way, the Court can also 'defend' its jurisdiction in opposition to national courts, since it reviews the contested measure solely against the background of Union law. ${ }^{84}$ This is highly relevant in relation to administrative measures which require awarding the addressee a right to be heard or the right to defence. Since these rights are recognised not only in many national legal orders but also under Union law, the Court will be willing to review a Union measure based on the claim that this measure is illegal, due to the fact that these rights were violated by the national authority while adopting the preparatory measure.

To conclude, it can be argued that the approach towards derivative illegality chosen by the Court is guided by the effort to reconcile the principle of legality with that of autonomy: the Court is willing to accept derivative illegality as long as the unlawfulness of the national measure stems from a breach of Union law. That way the Court can review the validity of the final measure without breaching the principle of autonomy.

\footnotetext{
Brito Bastos (n. 64) 121-132.

Ibid 121.

See e.g. Case T-247/16 Fursin and Others $v$ ECB application pending.

Case C-32/95 P Lisrestal / Commission EU:C:1996:402, see Case T-450/93; Joined Cases C-106/90, C-317/90 and C-129/91 Emerald Meats Ltdv Commission of the European Communities EU:C:1993:19.

84 Brito Bastos (n. 64) 126-132.
} 


\section{Applicability of the case law on derivative illegality to revocation}

An applicant in an action for annulment on grounds of derivative illegality is likely to argue that the unlawfulness of the national measure contaminated the final Union decision, which therefore needs to be declared invalid. In the case of revocation, the applicant is likely to argue that the national measure was lawful and therefore, in line with the Court's established case law on revocation; the Bank had no right to withdraw it, meaning that the Bank's revocation decision should be declared invalid.

Despite the potentially different circumstances leading an applicant to claim the invalidity of the Union measure, cases of derivative illegality and revocation decisions bear a crucial similarity: the Court is asked to review the lawfulness of a measure adopted by a national authority in order to determine the validity of a Union measure. The underlying tension between the principles of legality and autonomy applies.

This paper therefore argues that the general approach chosen by the Court in cases of derivative illegality in composite procedures can be applied to revocation cases. It points to three situations in which the Court can rule on the validity of a revocation decision of the Bank, without overstepping the limits of the autonomy principle. (1) When the review of the revocation decision suffices to determine the unlawfulness of the national measure; (2) when the review requires the Court to assess the lawfulness of a national measure in the light of procedural rules and requirements recognised under Union law; and (3) when the assessment of the national measure amounts to a review of law covered by Article 4(3) Basic Regulation.

First, the revoked and the revocation decisions will regard the same subjectmatter, and will be taken on the basis of the same provision granting the national authority and the Bank the competence to adopt it. The Bank will therefore make the same assessment as the national authority before adopting a revocation decision. ${ }^{85}$ It is supposed that the Bank is led to reassess the national decision due to a suspicion that an error, e.g. of a factual assessment or in a procedure, occurred during the adoption at the national level. It therefore revokes (and replaces) the national decision. As long as this error were to render the national measure unlawful, the review of the Court can focus on the revocation decision, in particular on the correction the Bank made in order to rectify the mistake by the national authority. Should the Court determine that the Bank adopted a lawful decision, it can conclude that the national decision was unlawful.

85 The Bank is under Article 296 TFEU as well as Article 33 Framework Regulation obliged to state reasons and motivate its decision. 
Second, certain procedural rights, such as e.g. the right to be heard or the right to receive a reasoned decision, are recognised under national laws as well as under European law. A breach of certain procedural rights can render a decision unlawful. Under an action for annulment, the Court can test the legality of a measure on the ground of a breach of essential procedural requirements. ${ }^{86}$ If the outcome of a procedure or the content of the adopted decision would have been substantially different if the procedural rule were not breached, then such a breach renders the decision unlawful. ${ }^{87}$ In case of revocation, the Court can test the lawfulness of the national measure in the light of procedural rights recognised under European law.

Third, under Article 4(3) Basic Regulation, the Bank is entitled to apply all relevant Union law. Where this Union law is composed of Directives, the Bank shall apply national legislation transposing those Directives. Where the relevant Union law is composed of Regulations and where currently those Regulations explicitly grant options for Member States, the Bank shall apply also the national legislation exercising those options. According to Article $26_{3}$ TFEU, the Court has jurisdiction to review the legality of the Bank's acts. This means that the Court will also review acts adopted by the Bank on the basis of national law in the sense of Article 4(3) Basic Regulation. This conclusion can easily be extended to the review of national measures. As long as the national authority based its decision on rules of Union law in the sense of Article 4(3) Basic Regulation, the Court should be able to review it in the light of such rules.

\section{Conclusion}

Europe's administrative order is changing. The Single Supervisory Mechanism is the most current and evident testimony of this. The unique competence division within the Mechanism between the Bank and the national authorities gives rise to a new phenomenon of Top-Down revocations.

Such revocations might occur when a national authority loses its supervisory competence over a credit institution to the Bank, and the Bank subsequently revokes a decision addressed to the credit institution adopted by the national authority.

Revocation decisions in general do not constitute a novelty under European Union law and have been subject to judicial review. One of the factors the Court takes into account is the (un)lawfulness of the revoked measure. Applied to the Top-Down revocation decisions, it means that the Court has to review the law-

86 Cf Article 263(2) TFEU.

87 E.g. Case 150/84 Bernardi EU:C:1986:167 para 28; Case T-240/10 Hungary v Commission EU:T:2013:645 para 84 . 
fulness of the national measure in order to determine the validity of the revocation decision and thus fulfil its obligation under Article 19(1) TEU to guarantee the legality of European Union action. Yet, such an incidental review of a national decision might be at odds with the principle of autonomy which prohibits Union measures to be reviewed in the light of national law.

The paper argues that this is not the first time the Court is facing a challenge to reconcile the principle of legality with that of autonomy: already in cases of derivative illegality occurring in composite procedures, the Court had to find a balance between these two principles. The paper therefore applies the Court's approach to derivative illegality to Top-Down revocations. It concludes that the Court can review Top-Down revocation decisions in three distinct situations: (1) When the review of the revocation decision suffices to determine the unlawfulness of the national measure; (2) when the review requires the Court to assess the lawfulness of a national measure in the light of procedural rules and requirements recognised under Union law; and (3) when the assessment of the national measure amounts to a review of law covered by Article 4(3) Basic Regulation. Such a review is capable of determining the legality of the Top-Down revocation decision, yet it is at the same time conducted in the light of European Union law which means that it does not jeopardise the autonomy principle. 